\title{
Tree Growth Response of Pinus oocarpa Along Different Altitude in Dedza Mountain Forest Plantation
}

\author{
Anderson Ndema, Edward Missanjo \\ Department of Forestry, Malawi College of Forestry and Wildlife, Dedza, Malawi \\ Email address: \\ andersoneendema@gmail.com (A. Ndema),edward.em2@gmail.com (E. Missanjo)
}

To cite this article:

Anderson Ndema, Edward Missanjo. Tree Growth Response of Pinus oocarpa Along Different Altitude in Dedza Mountain Forest Plantation. Agriculture, Forestry and Fisheries. Vol. 4, No. 1, 2015, pp. 24-28. doi: 10.11648/j.aff.20150401.15

\begin{abstract}
Understanding of the effects of altitude on tree growth is central to forest management, especially in the establishment of seed source stands. A study was conducted to investigate the effect of altitude on the growth height, diameter at breast height (dbh) and volume of Pinus oocarpa in Malawi. Stands of Pinus oocarpa at the altitude of $1500 \mathrm{~m}$, 1700m and $1900 \mathrm{~m}$ above the sea level (asl) were measured for total height, dbh and volume at the age of 18 years. Data obtained were subjected to analysis of variance. The results shows that there were significant $(P<0.001)$ differences in total mean height, dbh and volume among the different altitudes. Higher mean height $(19.2 \mathrm{~m})$, dbh $(24.5 \mathrm{~cm})$ and volume $\left(0.417 \mathrm{~m}^{3}\right)$ was observed at $1500 \mathrm{~m}$ asl, while total mean height, dbh and volume at $1700 \mathrm{~m}$ asl and $1900 \mathrm{~m}$ asl were $17.1 \mathrm{~m}, 22.9 \mathrm{~cm}, 0.322 \mathrm{~m}^{3}$ and $15.4 \mathrm{~m}$, $20.8 \mathrm{~cm}, 0.243 \mathrm{~m}^{3}$ respectively. Total mean height, $\mathrm{dbh}$ and volume decreased with an increase of altitude. This was attributed to differences in supply of soil nutrients and specific leaf area. It is therefore, recommended that seed sources stands for Pinus oocarpa in Malawi and the surrounding countries should be established at $1500 \mathrm{~m}$ to $1600 \mathrm{~m}$ above the sea level for better genetic growth parameters.
\end{abstract}

Keywords: Total Height, Diameter at Breast Height, Volume, Specific Leaf Area

\section{Introduction}

Understanding of the effects of altitude on tree growth is essential for improvement of forest cover as well as central to forest management [1], especially in the establishment of seed source stands [2]. Various studied on the effect of altitude on tree growth in different species have been conducted by many researchers $[1,3-12]$. However, mixed results have been reported. A reduction in tree height and diameter with an increase in altitude was observed in various studies $[1,3-5]$. On the other hand, there were no significant differences in tree height and diameter growth due to different altitudes [6-8].

Pinus oocarpa Schiede ex Schltdl. is one of the major exotic plantation species in Malawi and other Southern African countries. This species of pine tree is native to Mexico and Central America [13]. It is a national tree of Honduras, where it is known as Ocote [14]. Trees of Pinus oocarpa can be recognized by their irregular crowns, thick, gray, platy bark, ovoid-shaped cones with a large thick peduncles, and needles in fascicles of five. The tree species occurs from 350 to 2500 $\mathrm{m}$ above the sea level in Mexico and Central America but reaches its best development between 1200 and $1800 \mathrm{~m}$ above the sea level where the soils are deep and annual rainfall are above $1200 \mathrm{~mm}$. The growth rates in these regions are approximately 3 to $4 \mathrm{~m}^{3}$ per hectare per year [15]. Tree size varies considerably over its range; heights up to $37 \mathrm{~m}$; diameters 40 to $80 \mathrm{~cm}$ and occasionally $127 \mathrm{~cm}$. Boles are cylindrical, straight and clear up to $15 \mathrm{~m}$ or more and it is fire resistant [16]. Nevertheless, the tree grows poorly and reach the height of 10 to $15 \mathrm{~m}$ in northern Mexico, where the climate is drier than in most parts of Central America. Trees are also often less than 10 to $12 \mathrm{~m}$ height where they grow at elevations below 800 to $900 \mathrm{~m}$ above the sea level or on shallow, eroded soil on ridge tops. The growth rate in these dry regions is approximately $1 \mathrm{~m}^{3}$ per ha per year [15]. Pinus oocarpa has a seed potential of about 140 seeds per cone. The number of seeds per kg varies from 43000 to 78000 and in Guetamala the seed size was found to decrease with increasing elevation [15, 16]. In contrast, seed yields are poor for Pinus oocarpa planted as exotic near the equator but improve with increasing latitude [15]. For example, Arce and Isaza [17], as reported by [15], 
found only seven filled seeds per cone in stands established between $1360 \mathrm{~m}$ and $1800 \mathrm{~m}$ above the sea level of 12 to 21 years of age in Columbia ( $2^{\circ} \mathrm{N}$ latitude), while about 25 filled seeds per cone were found in Venezuela $\left(10^{\circ}\right.$ to $11^{\circ} \mathrm{N}$ latitude) in stands 10 to 12 years of age when established above $800 \mathrm{~m}$ above the sea level. Seeds of Pinus oocarpa usually will begin to germinate in 7 to 10 days using standard nursery or laboratory techniques. Seedlings reach a planting height of 20 to $25 \mathrm{~cm}$ in 5 to 7 months [15]. Pinus oocarpa is an important timber tree. The wood is easy to work with hand and machine tools. In Mexico and Central America, the wood is used for plywood, construction lumber, packing boxes, fuel wood, kindling as well as resin production [14].

The tree species was introduced in Malawi in 1950's for timber and it is now grown in most parts of the country at different altitudes. There is a general agreement in literature that growth of Pinus oocarpa varies according to location [14, 15]. Despite this, no information is available on the growth performance of Pinus oocarpa at different altitudes in Malawi. Therefore, the purpose of this study was to investigate the influence of altitude on the growth performance of Pinus oocarpa in Malawi. The information on growth performance of Pinus oocarpa at different altitude would be incorporated into decision support system in Malawi to assist the forestry industry in planning and establishment of best seed sources sites with high genetic growth parameters.

\section{Methods}

\subsection{Study Site}

This study was conducted in Malawi near the tropical savannah region in Southern Africa at Dedza Mountain Forest Plantation (Figure 1). Dedza Mountain lies on latitude $14^{0} 20^{\prime} \mathrm{S}$ and longitude $34^{\circ} 20^{\prime} \mathrm{E}$ and it rises up to about $2200 \mathrm{~m}$ above the sea level. It receives $1200 \mathrm{~mm}$ to $1800 \mathrm{~mm}$ rainfall per annum, with annual temperature ranging from 7 ${ }^{0} \mathrm{C}$ to $25{ }^{0} \mathrm{C}$ (Figure 2). The soils are high in ferralsols, acrisols and nitosols. It is situated about $85 \mathrm{~km}$ southeast of Lilongwe, the capital.

\subsection{Forest Stands, Plots and Data Collection}

Seedlings of Pinus oocarpa at the age of six month after pricking out were planted on nine compartments of 1.2 ha each at three different altitudes $(1500 \mathrm{~m}, 1700 \mathrm{~m}$, and $1900 \mathrm{~m}$ above the sea level) in 1994. Each altitude had three compartments, totalling to 10.8 ha area planted. The mean height and root collar diameter of the seedlings were $26.8 \mathrm{~cm}$ and $5.1 \mathrm{~mm}$ respectively. Hole planting was done at a spacing of $2.75 \mathrm{~m} \times 2.75 \mathrm{~m}$ (1320 stems ha') in all the compartments. Low thinning was carried out at the age of 9 and 15 years by removing $35 \%$ and $28 \%$ of the trees respectively. At the ages of 4, 9 and 15 years pruning was carried out in all the compartments. Trees were pruned to half of the stem height.

At the age of 18 years, 250 trees per compartment were systematically selected and measured for total height, diameter breast height (dbh) (1.3m above the ground) and volume. Suunto clinometer and calliper were used to measured total height and $\mathrm{dbh}$ respectively, while tree volume was calculated from the tree diameter and height using a tree volume function [18]. The longest fresh needle found on ground for the measured trees were also measured by a $30 \mathrm{~cm}$ ruler. Eight circular sample plots of 0.05 ha each were systematically constructed in each compartment and total number of trees were counted. This was done in order to determine the stocking per hectare for each altitude so that the natural mortality rate at each altitude is known. The stocking per hectare and natural mortality rate was calculated using formula's as expressed by [18]. Prior to tree measurement soil analysis was done. Site characteristics information is presented in Table 1.

Table 1. Site description.

\begin{tabular}{llll}
\hline Altitude (m asl) & $\mathbf{1 5 0 0}$ & $\mathbf{1 7 0 0}$ & $\mathbf{1 9 0 0}$ \\
\hline Longitude; & $34^{0} 20^{\prime} \mathrm{E} ;$ & $34^{0} 19^{\prime} \mathrm{E} ;$ & $34^{0} 19^{\prime} \mathrm{E} ;$ \\
Latitude & $14^{0} 22^{\prime} \mathrm{S}$ & $14^{0} 22^{\prime} \mathrm{S}$ & $14^{0} 21^{\prime} \mathrm{S}$ \\
Slope (\%) & 6 & 10 & 10 \\
Aspect & East & East & East \\
Soil pH $\left(\mathrm{H}_{2} \mathrm{O}\right)$ & 6.4 & 6.3 & 6.3 \\
$\mathrm{P}\left(\mathrm{mg} \mathrm{kg}^{-}\right)$ & 14.7 & 10.6 & 6.50 \\
$\mathrm{Zn}\left(\mathrm{mg} \mathrm{kg}^{-}\right)$ & 0.59 & 0.48 & 0.41 \\
$\mathrm{Fe}\left(\mathrm{mg} \mathrm{kg}^{-}\right)$ & 5.77 & 5.71 & 5.62 \\
$\mathrm{Mn}\left(\mathrm{mg} \mathrm{kg}^{-}\right)$ & 5.98 & 5.73 & 5.46 \\
\hline
\end{tabular}

\subsection{Statistical Analysis}

Data obtained were tested for normality and homogeneity with Kolmogorov-Smirnov D and normal probability plot tests using Statistical Analysis of Systems software version 9.1.3 [19]. After the two criteria were met the data were subjected to analysis of variance (ANOVA) using the same Statistical Analysis of Systems software and means were separated with Fischer's least significant difference (LSD) at the 0.05 level.

\section{Results and Discussion}

Mean height, dbh and volume growth are presented in Table 2. The results shows that there were significant $(P<0.001)$ differences in mean height, dbh and volume of Pinus oocarpa among the altitudes. The altitude of $1500 \mathrm{~m}$ above the sea level had higher values of mean height, dbh and volume than the altitudes of $1700 \mathrm{~m}$ and $1900 \mathrm{~m}$ above the sea level. Mean height, dbh and volume decreased with an increase in altitude. However, diameter increment declined less, $6.5 \%$ and $15 \%$ from $1500 \mathrm{~m}$ to $1700 \mathrm{~m}$ and from $1500 \mathrm{~m}$ to 1900 , with increasing elevation than height, $11 \%$ and $20 \%$ respectively. There was a similar trend for dbh growth and volume growth. The reason behind this is that dbh is highly positively correlated with volume [20].

The present results are in agreement to those in literature [1, 3-5, 9-12]. Growth rates may decline with increased altitude due to reduced air and soil temperature (an adiabatic effect), increased exposure to wind, and reduced supply of nutrients [4]. This may be true for the present study since nutrients decreased with an increase of altitude (Table 1). Coomes and Allen [4] reported that phosphorus availability is known to 
decline with an increasing altitude and this may contribute to the slow growth at high altitudes. On the other hand, [6-8] did not find a statistically significant effect of change in altitude on tree diameter. These differences may be attributed to the fact that various sites factors influence diameter growth [12].

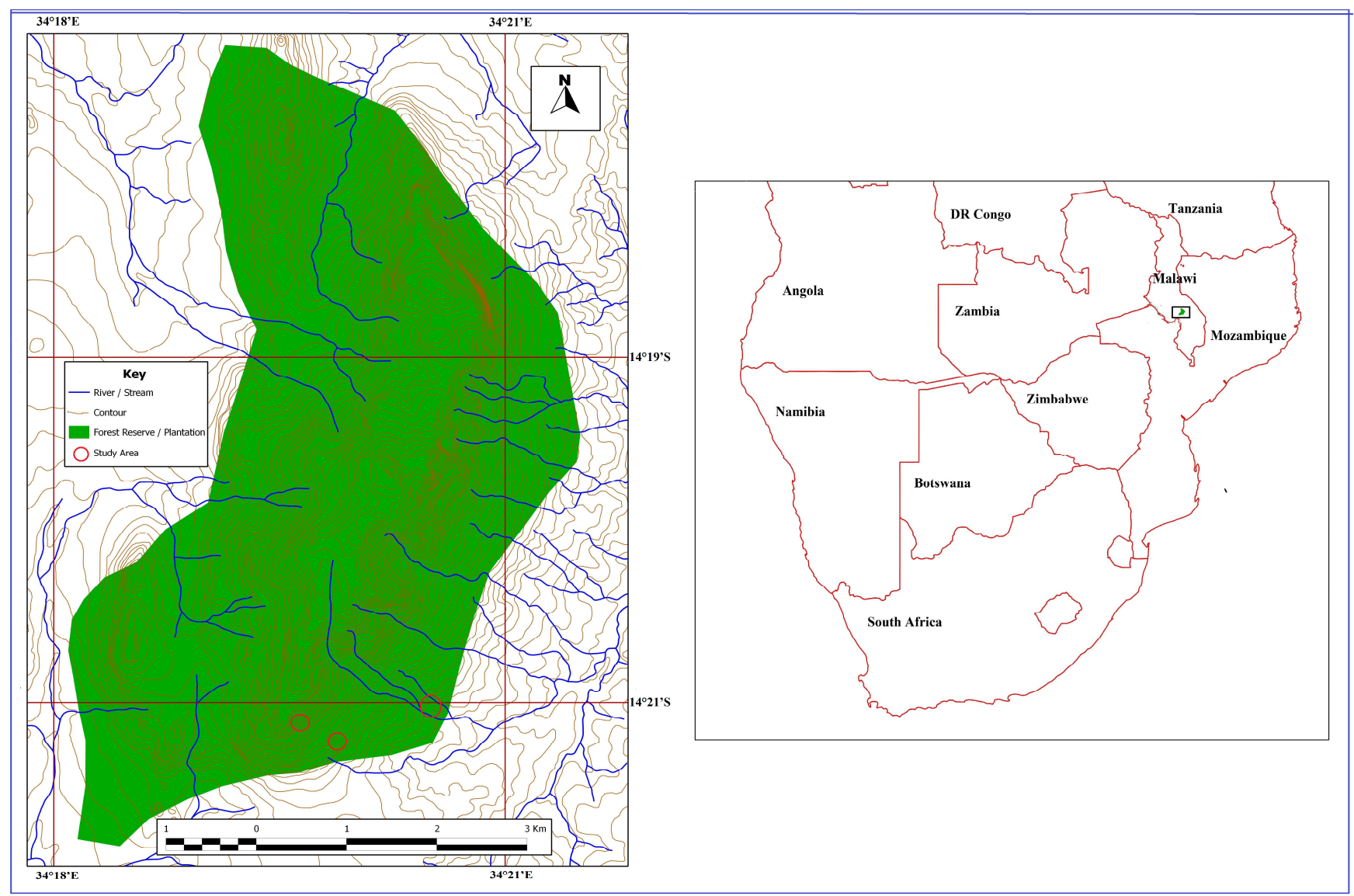

Figure 1. Location of Dedza Mountain in Southern Africa

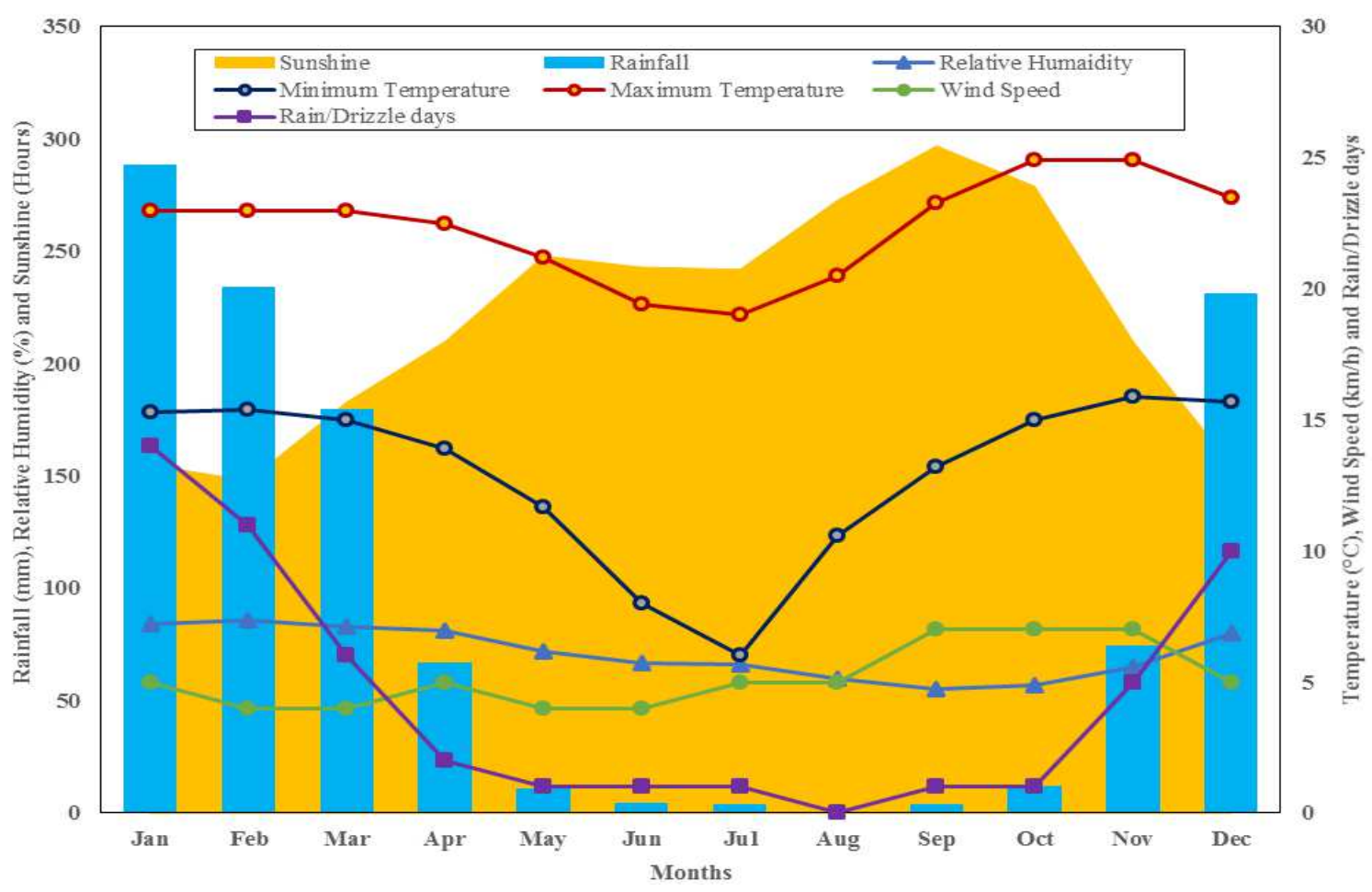

Figure 2. Weather for the study area 
Table 2. Mean height, diameter at breast height (dbh) and volume of Pinus oocarpa at the age of 18 years for different altitudes.

\begin{tabular}{llll}
\hline Altitude $(\mathbf{m}$ asl) & Height $(\mathbf{m})$ & dbh $(\mathbf{c m})$ & Volume $\left(\mathbf{m}^{3}\right)$ \\
\hline 1900 & $15.4 \pm 0.6^{\mathrm{c}}$ & $20.8 \pm 0.2^{\mathrm{c}}$ & $0.243 \pm 0.005^{\mathrm{c}}$ \\
1700 & $17.1 \pm 0.5^{\mathrm{b}}$ & $22.9 \pm 0.2^{\mathrm{b}}$ & $0.322 \pm 0.004^{\mathrm{b}}$ \\
1500 & $19.2 \pm 0.5^{\mathrm{a}}$ & $24.5 \pm 0.3^{\mathrm{a}}$ & $0.417 \pm 0.005^{\mathrm{a}}$ \\
$\mathrm{CV}(\%)$ & 7.9 & 6.3 & 19.6 \\
\hline
\end{tabular}

Note: ${ }^{\mathrm{a}, \mathrm{b}, \mathrm{c}}$ means with different subscript within a column significantly differ $(P<0.001)$

Table 3 shows that there were significant $(P<0.001)$ differences in estimated stocking per hectare among the different altitudes and these lead to the significant differences in natural mortality rate per year among the different altitudes. Natural mortality rate increased with an increase in altitude. Looking at this one would expect that trees grown at $1900 \mathrm{~m}$ above the sea level would have higher values of mean height and dbh than those grown at $1700 \mathrm{~m}$ and $1500 \mathrm{~m}$ above the sea level. This is so because trees grown at $1900 \mathrm{~m}$ above the sea level have more space, hence the competition for light is less, which could result in high rate of photosynthesis than those grown at $1700 \mathrm{~m}$ and $1500 \mathrm{~m}$ above the sea level. However, the results were opposite. This was attributed to the length of the needles. The length of needles decreased with an increase of altitude (Table 3). The present results are in agreement to those in literature [21, 22]. Grace [21] reported that morphological characteristics of needles change with altitude, thus at higher altitudes needles were shorter as a result they demonstrated a lower specific leaf area. This implies a diminished importance of any trend towards increased surface conductances, hence low rate of photosynthesis.

The length of needles at higher altitudes decreases as a result of an increase in wind [21]. As wind increases with an increase in altitude, a rapid increase in damage to leaves (needles) caused by mutual abrasions of the plants parts and blown soil particles is also expected [23], such damage may not only increase transpiration, but it may disrupt the turgor relations of the epidermis and thus prevent proper stomatal closure [22]. Therefore, the decrease in length of needles is attributed to stomatal dysfunction caused by mechanical damage to the leaf and also by damage to the epidermis [21]. The present study has shown that the growth of Pinus oocarpa decreases with an increase in altitude. It is therefore, recommended that seed sources stands for Pinus oocarpa in Malawi and the surrounding region should be established at $1500 \mathrm{~m}$ to $1600 \mathrm{~m}$ above the sea level for better genetic growth parameters.

Table 3. Expected and estimated stocking per hectare, natural mortality rate per year and mean needle length for Pinus oocarpa at different altitudes.

\begin{tabular}{lllll}
\hline Altitude (m asl) & $\begin{array}{l}\text { Expected stocking } \\
\text { (stems ha) }\end{array}$ & $\begin{array}{l}\text { Estimated stocking } \\
\text { (stems ha) }\end{array}$ & $\begin{array}{l}\text { Natural mortality rate } \\
\text { per year (\%) }\end{array}$ & Mean Needle length (cm) \\
\hline 1900 & $620 \pm 3$ & $559 \pm 4^{\mathrm{c}}$ & $0.55 \pm 0.02^{\mathrm{c}}$ & $15.4 \pm 0.8^{\mathrm{c}}$ \\
1700 & $620 \pm 3$ & $572 \pm 3^{\mathrm{b}}$ & $0.43 \pm 0.01^{\mathrm{b}}$ & $18.7 \pm 0.6^{\mathrm{b}}$ \\
1500 & $620 \pm 3$ & $598 \pm 4^{\mathrm{a}}$ & $0.20 \pm 0.02^{\mathrm{a}}$ & $21.2 \pm 0.9^{\mathrm{a}}$ \\
$\mathrm{CV}(\%)$ & & 8.2 & 8.1 & 5.3 \\
\hline
\end{tabular}

Note: ${ }^{\mathrm{a}, \mathrm{b}, \mathrm{c}}$ means with different subscript within a column significantly differ $(P<0.001)$

\section{Conclusion}

The present study has revealed that altitude has a clear effect on growth height, diameter at breast height and volume of Pinus oocarpa. Total height, dbh and volume decreases with an increase in altitude. It is therefore, recommended that seed sources stands for Pinus oocarpa in Malawi and the surrounding region should be established at $1500 \mathrm{~m}$ to $1600 \mathrm{~m}$ above the sea level for better genetic growth parameters.

\section{Acknowledgements}

The authors are grateful to the staff at Dedza District Forestry Office for allowing the study to be conducted at Dedza Mountain Forest Plantation and also for the assistance provided during data collection.

\section{References}

[1] Yang Y., Watanabe M., Li F., Zhang J., Zhang W., and Zhai J., 2006, Factors affecting forest growth and possible effects of climate change in the Taihang Mountains, northern China. Forestry, 79(1), $135-147$.

[2] Vitasse Y., Delzon S., Bresson C.C., Michalet R., and Kremer A., 2009, Altitudinal differentiation in growth and phenology among populations of temperate-zone tree species growing in a common garden. Canadian Journal of Forest Research, 39, $1259-1269$.

[3] Pacalaj M., Longauer R., Krajmerova D., and Gomory D., 2002, Effect of site altitude on the growth and survival of Norway spruce (Picea abies L.) provenances on the Slovak plots of IUFRO experiment 1972. Journal of Forest Science, $48(1), 16-26$. 
[4] Coomes D.A., and Allen R.B., 2007 Effects of size, competition and altitude on tree growth. Journal of Ecology, $95,1084-1097$.

[5] King G.M., Gugerli F., Fonti P., and Frank D.C., 2013, Tree growth response along an elevational gradient: climate or genetics? Oecologia, doi: 10.1007/s00442-013-2696-6.

[6] Li M.H., Yang J., and Kräuchi N., 2003, Growth responses of Picea abies and Larix decidua to elevation in subalpine areas of Tyrol, Austria. Canadian Journal of Forest Research, 33, $653-662$.

[7] Norton D.A., 1985, A dendrochronological study of Nothofagus solandri tree growth along an elevational gradient, South Island, New Zealand. Eidg. Anst. Forstl. Versuchswes. Ber., 270, $159-171$.

[8] Weber U.M., 1997, Dendroecological reconstruction and interpretation of larch budmonth (Zeiraphera diniana) outbreaks in two central alpine Valleys of Switzerland from 1470-1990. Trees, 11, $277-290$.

[9] Körner C., 1998, A re-assessment of high elevation tree line positions and their explanation. Oecologia, 115, $445-459$.

[10] Körner C., 1999, Alpine plant life. Springer-Verlag: Berlin, Germany.

[11] Paulsen J., Weber U.M., and Körner C., 2000, Tree Growth near Tree line: Abrupt or Gradual Reduction with Altitude? Arctic, Antarctic and Alpine Research, 32, 14 - 20.

[12] Tranquillini W., 1979, Physiological Ecology of the Alpine Timberline: Tree existence at high altitudes with special references to the European Alps. Ecological Studies (Analysis and Synthesis), Vol. 31, Springer-Verlag: Berlin, Heidelberg, New York.

[13] Zenni R.D., and Ziller S.R., 2011, An overview of invasive plants in Brazil. Brazilian Journal of Botany, 34, 431 - 446.
[14] Braga E.P., Zenni R.D., and Hay J.D., 2014, A new invasive species in South America: Pinus oocarpa Schiede ex Schltdl. BioInvasions Records, 3(3), 207-211.

[15] Dvorak W.D., 2005, Pinus oocarpa Schiede ex Schltdl. CAMCORE, 2, $628-631$.

[16] Dvorak W., 2002, Pinus oocarpa Schiede ex Schltdl. In: Vozzo J (ed), Tropical Tree Seed Manual. U.S. Department of Agriculture, Forest Service: United States.

[17] Arce M., and Isaza N., 1996, Producción de semillas por cono en cuatro especies del género Pinus en Colombia. Informe de investigación No. 173. Investigación Forestal. Smurfit Cartón de Colombia.

[18] Ingram C.L., and Chipompha N.W.S., 1987, The Silvicultural Guide Book of Malawi, 2nd edition. FRIM: Malawi.

[19] SAS 9.1.3., 2004, Qualification Tools User's Guide. SAS Institute Inc., Cary, NC, USA.

[20] Missanjo E., Kamanga-Thole G., and Manda V., 2013, Estimation of Genetic and Phenotypic Parameters for Growth Traits in a Clonal Seed Orchard of Pinus kesiya in Malawi. ISRN Forestry, Volume 2013, Article ID 346982, 6 pages, doi:10.1155/2013/346982.

[21] Grace J., 1990, Cuticular water loss unlikely to explain treeline in Scotland. Oecologia, 84, $64-68$.

[22] Pitcairn C.E.R., Jeffree C.E., and Grace J., 1986, Influence of polishing and abrasion on the diffusive conductance of leaf surface of Festuea arundinacea Schreb. Plant Cell Environment, 9,191 - 196.

[23] Hadley J.L., and Smith W.K., 1986, Wind effects on needles of timberline conifers: seasonal influence on mortality. Ecology, 67, $12-19$ 